Jurnal Qua Teknika, Vol. 7 No. 2 September 2017

ISSN 2088 2424(cetak); 2527 3892(elektronik)

UNISBA Blitar, Http:// qua.unisbablitar.ejournal.web.id

Syamsudin Nur Wahid, Achendri M Kurniawan. 2017. Rancang Bangun Permainan Ular Tangga untuk Media Belajar Fisika. Jurnal Qua Teknika, (2017), 7(2):43 53.

\title{
RANCANG BANGUN PERMAINAN ULAR TANGGA UNTUK MEDIA BELAJAR FISIKA
}

\author{
Syamsudin Nur Wahid, Achendri M Kurniawan \\ Fakultas Teknik, Universitas Islam Balitar \\ email: sn_wahid@unisbablitar.ac.id
}

\begin{abstract}
Abstrak
Fisika merupakan mata kuliah dasar yang harus dikuasai terutama oleh mahasiswa teknik, namun sulit dipahami sehingga prestasi belajarnya rendah. Untuk itu maka dibuat media belajar berupa Permaianan Ular Tangga untuk meningkatkan prestasi belajarnya. Permainan Ular Tangga dibangun dalam bentuk perangkat lunak disisipi dengan pertanyaan-pertanyaan mengenai suatu konsep pembelajaran. Permainan ini dirancang menggunakan aplikasi pemrograman Lazarus dengan ditunjang program aplikasi pengolah gambar. Penelitian ini menghasilkan permaianan pendidikan ular tangga yang dapat merangsang mahasiswa untuk belajar, khususnya untuk mata kuliah fisika. Permainan telah diujicoba dalam lingkungan sistem operasi windows 7, 64-bit, menggunakan prosesor AMD A6. Aplikasi telah berjalan dengan baik sesuai yang diharapkan. Permainan ini dapat dimainkan oleh 1-4 pemain. Permainan yang dimainkan oleh 1 pemain membutuhkan waktu minimal 4 menit untuk menyelesaikannya. Permainan yang dimainkan dengan 4 bidak dapat diselesaikan paling cepat dalam waktu 7 menit. Waktu penyelesaian permainan dapat bervariasi tergantung tingkatan tantangan soal dan kemampuan pemain. Permaian dapat berjalan lebih lama jika banyak pertanyaan yang jawabannya salah. Karena banyak yang jawabannya salah, maka tanatangannya akan semakin besar, semakin besar tantangan, maka pemain akan semakin terpacu untuk lebih banyak belajar.
\end{abstract}

Kata kunci: media belajar, ular tangga, perngkat lunak, permainan.

\section{PENDAHULUAN}

Fisika merupakan mata kuliah dasar yang harus dikuasai terutama oleh mahasiswa teknik. Kebanyakan sistem pembelajaran untuk mahasiswa yang ada sekarang ini, masih menggunakan metode ceramah, dosen mencatat di papan tulis dan mahasiswa menyalinnya sehingga proses pembelajaran berjalan lambat. Cara lain yang sering digunakan yaitu dengan media LCD, maka pembelajaran bisa berjalan lebih cepat dan mahasiswa dapat memahami materi lebih mudah. Materi pembelajaran yang hanya dipelajari sekali akan mudah dilupakan. Akibatnya nilai kuliah mereka rendah. Agar siswa benar-benar memahami dan dapat menerapkan apa yang diajarkan, mereka harus bekerja memecahkan masalah, menemukan segala sesuatu untuk dirinya (Supriana, 2011) sehingga nilai kuliah mereka menjadi lebih tinggi. Untuk itulah diperlukan media pembelajaran.

Ada beberapa macam media pembelajaran, yang paling umum digunakan yaitu buku, peralatan eksperimen (Supriana, 2011), software animasi (Dani, 2008), dan permainan. Permainan dapat berupa aktivitas fisik (Sugiyo, et al., 2008) atau menggunakan aplikasi software. Permainan sebagai media pembelajaran biasa disebut sebagai permainan pendidikan. Saat ini telah banyak dikembangkan permainan pendidikan untuk mendukung berbagai mata pelajaran, seperti sejarah (Widiastuti \& Setiawan, 2012), geografi (Novaliendry, 2013) dan fisika (Rodrigues \& Carvalho, 2013). Permainan yang sudah ada mungkin dapat digunakan untuk media belajar, namun terbatas pada bidang tertentu misalnya 
game angry bird dapat digunakan untuk mempelajari mekanika. Tetapi permainan baru perlu dikembangkan untuk menjelaskan hal lainnya.

Ular tangga merupakan permainan yang sudah lama dikenal masyarakat. Pembelajaran terselubung dapat digabungkan dengan sedikit memodifikasi game ini dalam bentuk software. Pada titik-titik tertentu diselipkan pertanyaan seputar fisika yang mengharuskan pemain mengerjakan soal tersebut agar dapat melanjutkan permainan. Karena adanya persoalan, pemain harus belajar jika tidak mengerti mengenai konsep yang bersangkutan. Karena adanya perasaan senang saat bermain, pemain tidak akan cepat merasa bosan. Permainan dapat dilakukan oleh satu atau beberapa orang. Saat dimainkan oleh beberapa pemain maka akan tercipta suasana belajar kelompok dan kompetisi antar pemain. Dengan berkompetisi, maka akan timbul semangat belajar pada setiap pemain. Dengan belajar kelompok, materi akan lebih cepat dipahami.

Permainan Ular tangga dikembangkan dengan program Lazarus karena tidak memerlukan animasi yang banyak. Lazarus juga mendukung user interface yang sangat familiar dan mudah mengatur file input-outputnya. Game ular tangga dikembangkan untuk pembahasan masalah fisika yang bersifat umum. Kedepannya game ini akan dikembangkan untuk mata kuliah lain karena sifatnya yang umum ini.

Berdasarkan pemaparan tersebut tujuan penelitian ini adalah membuat permainan ular tangga menjadi media belajar dengan menyisipkan soal fisika di dalamnya.

\section{KAJIAN LITERATUR}

Media adalah bagian yang tidak terpisahkan dari proses belajar mengajar demi tercapainya tujuan pendidikan pada umumnya dan tujuan pembelajaran di sekolah pada khususnya (Arsyad, 2000). Apabila media itu membawa pesan-pesan atau informasi yang bertujuan instruksional atau mengandung maksud-maksud pengajaran maka media itu disebut Media Pembelajaran (Arsyad, 2007).

Hamalik (1986) mengemukakan bahwa pemakaian media pengajaran dalam proses belajar mengajar dapat membangkitkan keinginan dan minat yang baru, membangkitkan motivasi dan rangsangan kegiatan belajar, dan bahkan membawa pengaruh-pengaruh psikologis terhadap siswa. (Arsyad, 2007)

Pengembangan media belajar untuk meningkatkan pemahaman siswa /peserta didik telah dilakukan oleh banyak peneliti. Pada 2011 Supriana mengembangkan perangkat percobaan fisika untuk mempelajari listrik dinamis (Supriana, 2011). Sebelumnya, Dani (2008) mengusulkan permainan atau game dan animasi sebagai media belajar yang interaktif dan atraktif untuk mengatasi keterbatasan akses pendidikan di Indonesia (Dani, 2008).

Permainan dapat berupa aktivitas fisik maupun dengan media komputer. Sugiyo dkk, (2008) menggunakan aktivitas Team Game Tournament untuk mendukung pelajaran kimia (Sugiyo, et al., 2008). Pada 2012 Widiastuti dkk mengembangkan game petualangan walisongo untuk mendukung pelajaran sejarah menggunakan algoritma $A^{*}$ (Widiastuti \& Setiawan, 2012). Noveliendri pada 2013 merancang game berbasis multimedia interaktif untuk mendukung mata pelajaran geografi (Novaliendry, 2013).

Selain mata pelajaran tersebut, tak ketinggalan pula untuk fisika. Sebagaimana telah diketahui bersama bahwa fisika merupakan cabang ilmu pengetahuan yang wajib dipejari oleh mahasiswa sains dan teknik. Fisika mempelajari berbagai benda fisik dari yang terbesar sampai yag terkecil. Beberapa bab yang dipelari di universitas antara lain: 1) Besaran dan Vektor, 2) Kinematika Gerak, 3) Dinamika Gerak, 4) Usaha dan Energi, 5) Sistem Partikel, 6) Fluida, 7) Getaran dan Gelombang, 8) Optik, 9) Listrik dan Magnet, 10) Kalor dan 11) Astrofisika. 
Telah banyak dikembangkan game yang mengadopsi konsep fisika, misalnya angry bird. Rodrigues menggunakan game ini untuk mengajarkan konsep dinamika dan kinematika gerak dengan bantuan software pengolah gambar (Rodrigues \& Carvalho, 2013). Umumnya permainan tersebut telah dirancang untuk mempelajari satu konsep saja, misalnya mekanika. Sedangkan untuk konsep lain perlu dibuat permainan lain. Untuk itu perlu dibuat permainan yang dapat dijadikan media untuk konsep yang lebih luas, mulai besaran, mekanika, termodinamina, elektromagnet hingga optik bahkan fisika modern. Maka persoalan dalam permainan tidak perlu dibuat dengan visualisasi yang rumit, cukup dengan tulisan dalam kalimat singkat. Metode ini sesuai untuk permainan ular tangga.

Ular tangga adalah permainan papan yang dimainkan oleh 2 orang atau lebih. Papan permainan dibagi dalam kotak-kotak kecil dan di beberapa kotak digambar sejumlah "tangga" atau "ular" yang menghubungkannya dengan kotak lain. Permainan ini diciptakan pada tahun 1870. (Wikipedia, 2013).

Ular tangga dimainkan dengan langkah-langkah sebagai berikut. Setiap pemain mulai dengan bidaknya di kotak pertama (biasanya kotak di sudut kiri bawah) dan secara bergiliran melemparkan dadu. Bidak dijalankan sesuai dengan jumlah mata dadu yang muncul. Bila pemain mendarat di ujung bawah sebuah tangga, mereka akan langsung pergi ke ujung tangga yang lain. Bila mendarat di kotak dengan ular, mereka harus turun ke kotak di ujung bawah ular. Pemenang adalah pemain pertama yang mencapai kotak terakhir. Bagan alur permainan ular tangga secara sederhana digambarkan seperti pada Gambar 1.

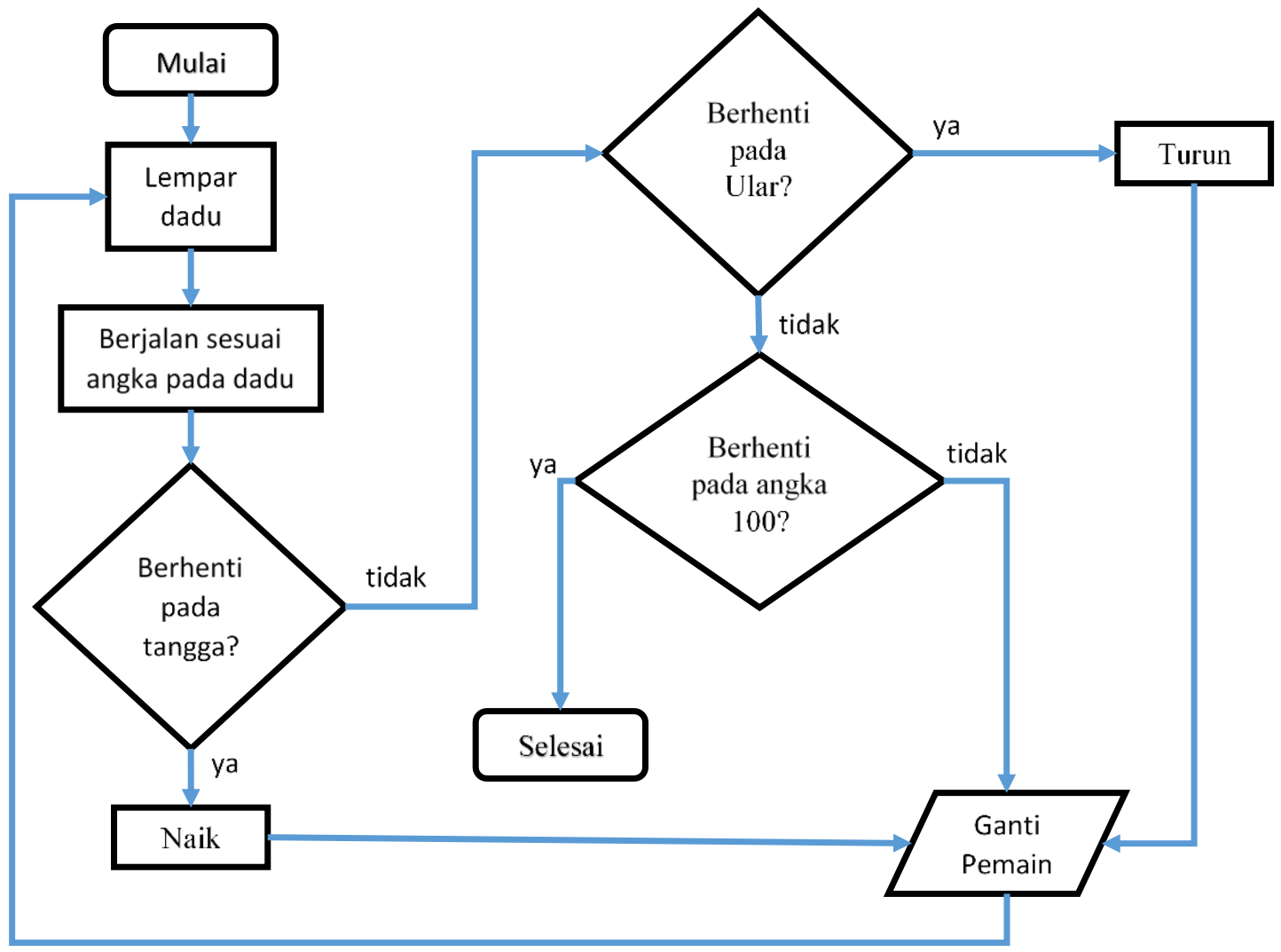

Gambar 1 diagram alir ular tangga

Banyak tool yang dapat dipakai untuk membuat permainan pendidikan, diantaranya adobe flash, eclipse, basic, $\mathrm{c}++$, blender, pascal dan sebagainya. Berangkat dari pengalaman peneliti yang sebelumnya menggunakan menggunakan Delphi untuk membuat software 
spada sebagai skripsi (Wahid, 2012), maka dipilahlah program Lazarus sebagai aplikasi pembangunnya.

Lazarus merupakan IDE platform-silang untuk Free Pascal yang kompatibel dengan Delphi. Program tersebut terdapat LCL yang kurang lebih kompatibel dengan VCL Delphi. Free Pascal merupakan kompiler GPL yang berjalan pada Linux, Win32, OS/2, 68K dan sebagainya. Free Pascal didesain untuk dapat mengerti dan mengkompilasi sintaksis Delphi, yang merupakan OOP. Lazarus adalah bagian dari teka-teki yang hilang yang mengizinkan programmer untuk membangun program seperti Delphi dalam semua platform diatas. Tidak seperti Java yang berusaha untuk menjadi sebuah 'write once run anywhere', Lazarus dan Free Pascal berusaha untuk 'write once compile anywhere'. Karena kompiler yang sama persis tersedia pada semua platform diatas, maka programmer tidak perlu melakukan suatu perekaman untuk menghasilkan produk yang mirip untuk platform yang berbeda. (Sourceforge, 2017)

\section{METODE}

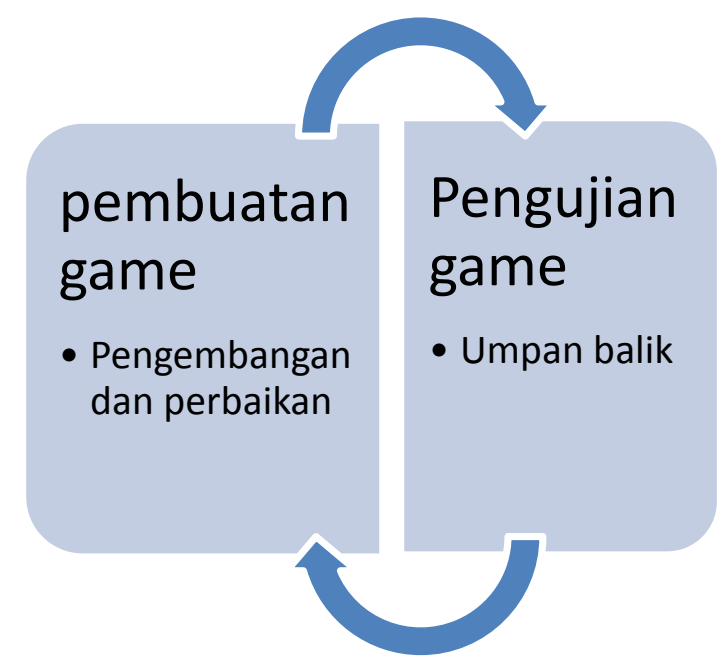

Gambar 2 Tahap Pembuatan dan Pengujian Permainan

Penelitian ini dibagi menjadi dua tahap. Tahap pertama ialah pembuatan permainan dan yang kedua adalah pengujian sebagaimana ditunjukkan pada Gambar 2. Setelah pengujian pasti ada umpan balik dari pengguna. Umpan balik ini akan digunakan untuk mengembangkan game ke arah lebih baik sebagai penelitian selanjutnya.

Tahap pertama dari pembuatan permainan yaitu membuat desain sistem. Sistem didesain berdasarkan permainan ular tangga secara umum dengan disisipi muatan pendidikan. Cara bermain permainan ular tangga ini adalah ditunjukkan seperti pada Gambar 3. Pertama pemain membuka permainan dengan menjalankan aplikasi dari direktori tempat ia disimpan. Kemudian pemain membuat permainan baru dengan mengisikan nama masing-masing bidak pemain. Permainan dapat dimainkan oleh 1-4 pemain. Setiap pemain melempar dadu secara bergiliran dan pionnya akan berjalan melewati setiap kotak secara otomatis berdasarkan angka yang keluar. Saat satu bidak pemain menemui tangga, akan muncul satu pertanyaan. Jika jawaban pemain tersebut benar dia akan dapat menaiki tangga, jika salah, dia diam. Permainan tidak dapat dilanjutkan sebelum pemain yang bersangkutan menjawab pertanyaan yang muncul. Saat satu bidak pemain menemui ular, akan muncul satu pertanyaan. Jika jawaban pemain tersebut benar dia akan tetap berada di tempatnya, jika salah, dia harus turun menurut arah yang dituju ular. Permainan tidak dapat dilanjutkan sebelum pemain yang 
bersangkutan menjawab pertanyaan yang muncul. Permainan berakhir ketika salah satu pemain mencapai kotak terakhir dengan angka 100.

Permainan dibuat menggunakan perangkat lunak Lazarus. Lazarus merupakan sarana pemrograman aplikasi visual. Bahasa pemrograman yang digunakan adalah Pascal. Adapun Game ular tangga dikembangkan dalam lingkungan bahasa pemrograman Lazarus berbasis Windows 7 Ultimate. Dalam game juga terdapat image dan shape sebagai papan permainan dan bidak pemain. Gambar dibuat dengan perangkat desain grafis.

Pada permainan ini terdapat 3 bagian form dan satu program bantu. Satu form untuk mengisikan nama-nama pemain, satu form untuk papan permainan dan satu form yang berisi identitas program. Sedangkan program bantu digunakan untuk mengisikan pertanyaan oleh pembuat soal. Papan permainan merupakan form utama yang dapat memanggil kedua form lainnya. Papan permainan berisi bidak tempat bermain, halaman untuk pertanyaan dan jawaban serta tombol kendali. Sebenarnya ada 1 form lagi yang berisi daftar pertanyaan dan tidak akan ditampilkan saat aplikasi dijalankan. Prosedur diterapkan pada masing-masing tombol kendali di masing-masing form.

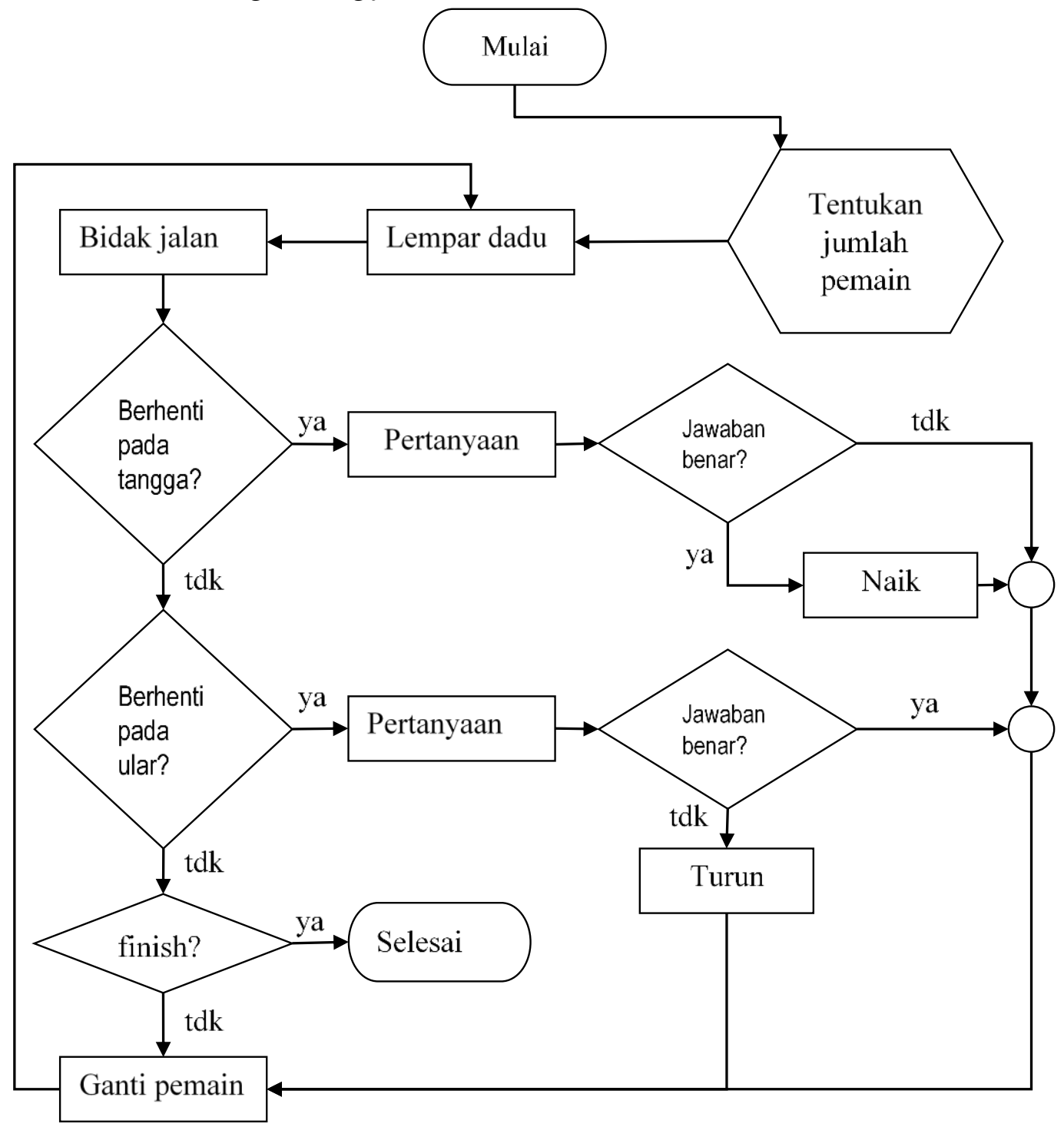

Gambar 3 Diagram alir permainan ular tangga 
Tombol kendali pada form utama berisi antara lain: baru, kocok, save dan open. Selain melalui tombol kendali, pemain juga dapat berinteraksi melalui baris menu, yaitu file, tingkatan dan tolong. Menu file berisi submenu baru, simpan dan buka. Menu tingkatan berisi pilihan tingkatan soal permainan, yaitu mudah, sedang, sulit dan campuran. Setiap tingkatan disesuaikan dengan capaian pembelajaran. Menu terakhir, tolong, berisi keterangan permainan dan petunjuk cara bermain.

Setiap tombol dan menu memiliki modul algoritma tersendiri sebagai penjabaran dari algoritma pada Gambar 3. Misalnya algoritma perjalanan bidak pada tombol kocok adalah sebagai berikut:

1. Acak dadu, munculkan angka 1-6.

2. Bidak berjalan satu lngkah maju, diulang sebanyak angka yang ditunjukkan dadu.

3. Jika bidak berada di angka yang puluhannya genap langkahnya ke kanan, jika ganjil ke kiri.

4. Jika bidak berhenti pada angka 100, permainan selesai.

5. Jika bidak berhenti pada angka lebih dari 100, maka langkahnya berbalik arah.

6. Jika bidak berhenti pada pangkal tangga atau ekor ular, maka munculkan pertanyaan, pasifkan tombol kocok. Jika tidak, lanjut ke nomor 7.

7. Ganti pemain lain, nama pemain selanjutnya ditampilkan, nama pemain sebelumnya disembunyikan.

8. Kembali ke nomor 1 untuk pemencetan tombol kocok selanjutnya.

\section{HASIL DAN PEMBAHASAN}

Pertama kali program dijalankan, pada layar muncul tampilan awal program seperti yang ditunjukkan pada Gambar 4. Form utama terdapat beberapa komponen, yaitu papan permainan, kumpulan tombol permainan baru, kocok, save dan open, bagian pertanyaan dan jawaban, tombol jawab yang aktif saat muncul pertanyaan, label yang mewakili dadu, shape pemain, dan main menu di baris atas. Berikut akan dibahas hasil dari aplikasi yang telah dibuat serta pengujian yang telah dilakukan. Pengujian dilakukan dengan metobe black box testing dalam lingkungan sistem operasi windows 7, 64-bit, dengan prosesor AMD A6 sebagaimana program ini dibuat.

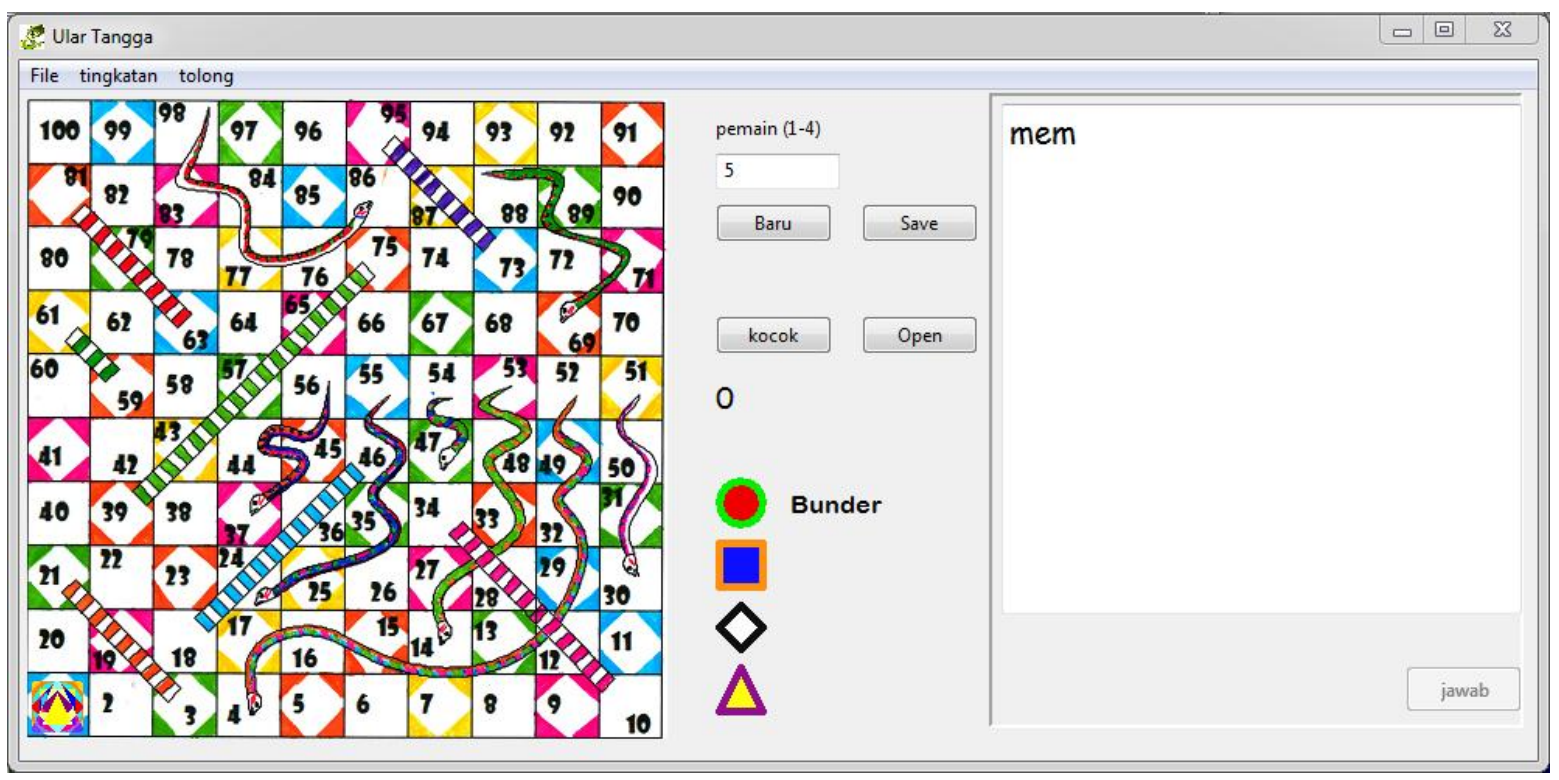

Gambar 4 Antarmuka aplikasi permainan ular tangga 
Main menu dihubungkan dengan tombol yang telah memiliki prosedur, terutama untuk menu File $\rightarrow$ (baru/ simpan/ buka). Menu tingkatan diberi fungsi dan prosedur tersendiri dan menu turunan merupakan radio button. Sedangkan menu tolong berisi link dan keterangan yang tidak mempengaruhi jalannya permainan. Keseluruhan main menu ditunjukkan pada Gambar 5. Hasil pengujian submenu 'baru', 'simpan' dan 'buka' akan dibahas bersamaan dengan tombol yang fungsinya sesuai dengan menu tersebut.

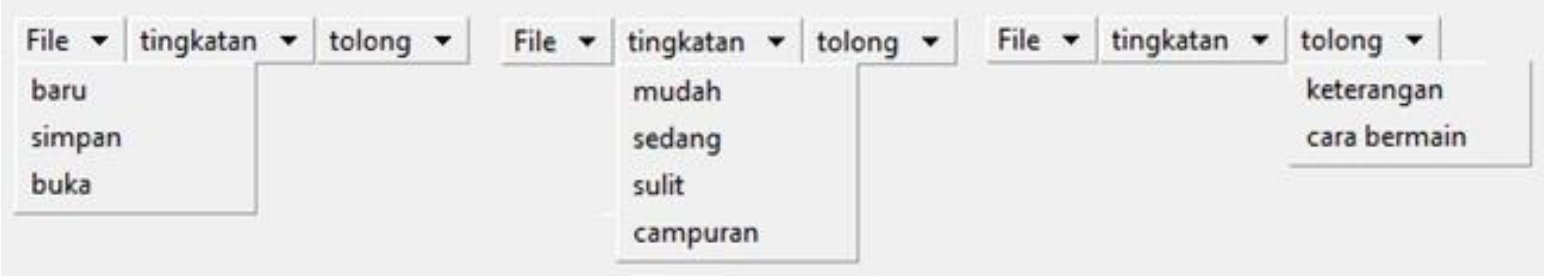

\section{Gambar 5 Main Menu}

Permainan baru dimulai dengan mengisikan jumlah pemain pada komponen edit di tengah form aplikasi. Maka akan muncul form untuk mengisikan nama bidak pemain saat tombol 'Baru' diklik atau melalui menu file $\rightarrow$ baru. Jika diisikan 4 pemain, maka akan muncul form yang tampak pada Kesalahan! Sumber referensi tidak ditemukan., secara default pemain memiliki nama bunder, kotak, kupat dan wajik pada setiap bidakya. Jika pemain setuju dengan nama ini maka tinggal mengklik tombol OK agar permainan bisa segera dimulai, jika tidak nama bisa diubah terlebih dahulu. Prosedur pada tombol baru telah berjalan dengan lancar, bidak yang muncul sesuai angka yang dimasukkan pada kolom pemain, asalkan pemain mengetikkan angka dengan benar. Jika yang diisikan bukan angka maka akan muncul peringatan seperti pada Gambar 7.

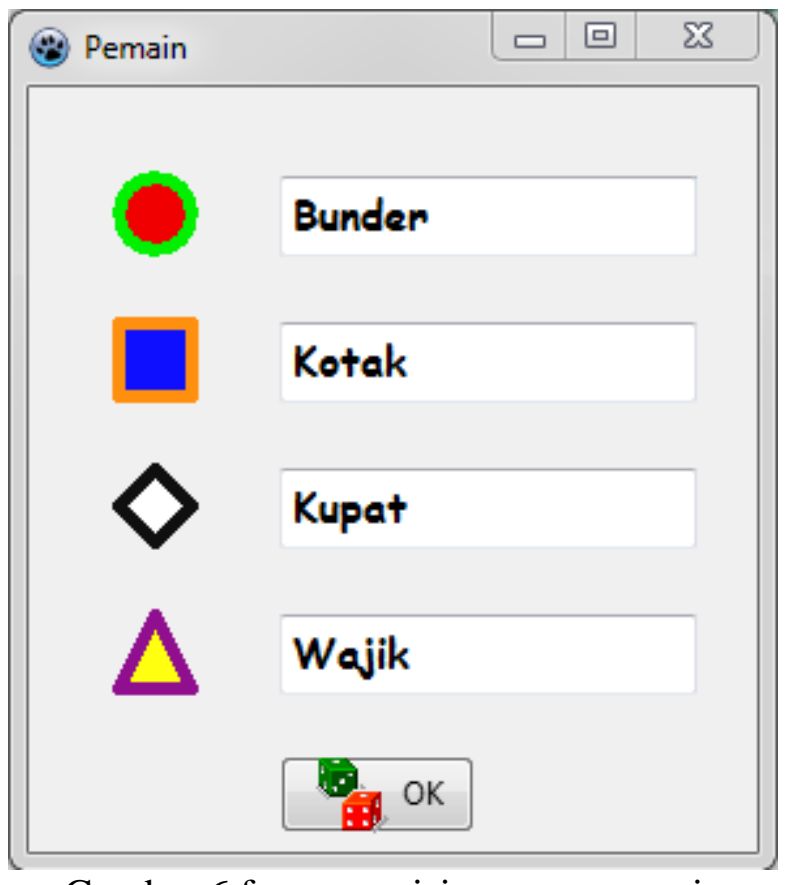

Gambar 6 form pengisian nama pemain

Pertama kali permainan dijalankan pemain berada pada tingkatan campuran. Ganti tingkatan dapat diakses melalui menu tingkatan $\rightarrow$ (mudah/ sedang/ sulit/ campuran). Ketika pemain berganti tingkatan, otomatis permainan baru dimulai dan semua bidak berada di 
nomor 1. Pergantian tingkatan tidak menampakkan adanya perubahan di form utama, yang berubah hanyalah tingkatan pertanyaan yang muncul saat bidak menemui ular atau tangga. Sejauh ini tidak ada masalah saat ganti tingkatan pertanyaan karena jumlah keseluruhan soal yang tersedia tidak lebih dari 100. Pergantian tingkatan tidak membutuhkan waktu lama dibandingkan dengan waktu yang dibutuhkan oleh pengguna untuk mengisikan nama pemain.

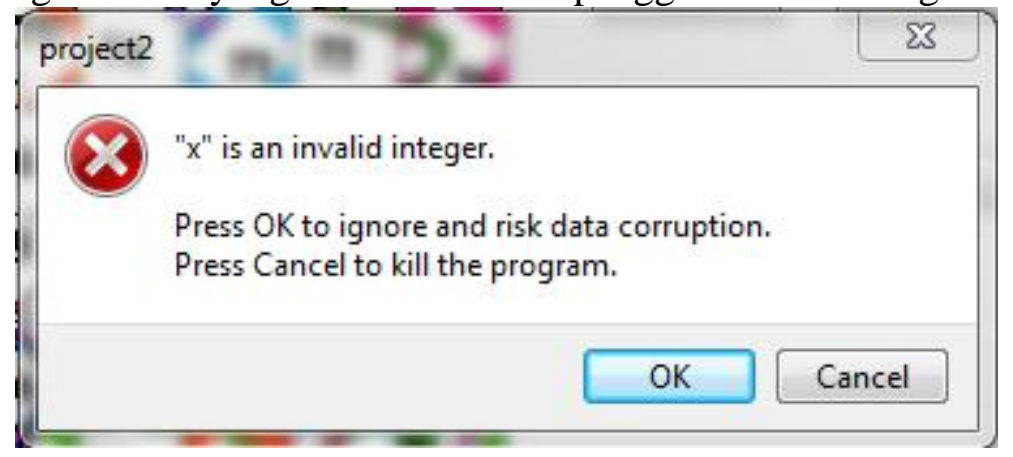

Gambar 7 Form peringatan masukan salah

Saat permainan baru dibuka, nama pemain serta bidaknya tidak ditampilkan. Saat permainan dimulai semua bidak berada di nomor 1 papan permainan seperti tampak pada Gambar 4 dan tombol kocok menjadi aktif. Bidak berjalan secara otomatis ketika tombol kocok ditekan.

Prosedur pada tombol kocok sudah berjalan dengan baik, dadu telah dikocok dengan sangat acak dan bidak telah berjalan dengan lancar. Perjalanan bidak tidak keluar dari kotakkotak bernomor yang telah ditentukan di dalam papan permainan. Terdapat beberapa bug dalam kasus-kasus tertentu. Saat permainan dimainkan oleh beberapa orang, di tengah permainan mereka memulai permainan baru, jatah giliran pemain lama tidak akan langsung hilang. Saat tombol kocok ditekan beberapa kali tanpa menunggu giliran maka dadu akan mengacak sendiri dan bidak akan berjalan otomatis sebanyak pemencetan tombol, walaupum menemui pertanyaan, jawaban apapun tidak akan berpengaruh. Saat bidak hampir mencapai angka 100 kemudian ia berjalan ke posisi yang lebih banyak dari 100, maka ia dapat berada di tempat yang salah saat perjalanan. Misal bidak berada di nomor 97, kemudian mengocok dadu dan keluar angka 6. Secara normal bidak akan berjalan melalui nomor 98-99-100-101102-103, tetapi angka 100 sudah maksimal. Dalam permainan aslinya bidak berjalan melalui nomor 98-99-100 dan kembali ke 99-98-97. Maka dalam permainan ini bidak melalui nomor 98-99-100-91-92-93 dan terakhir langsung ke nomor 97. Secara keseluruhan bug tersebut tidak mengganggu jalannya permainan.

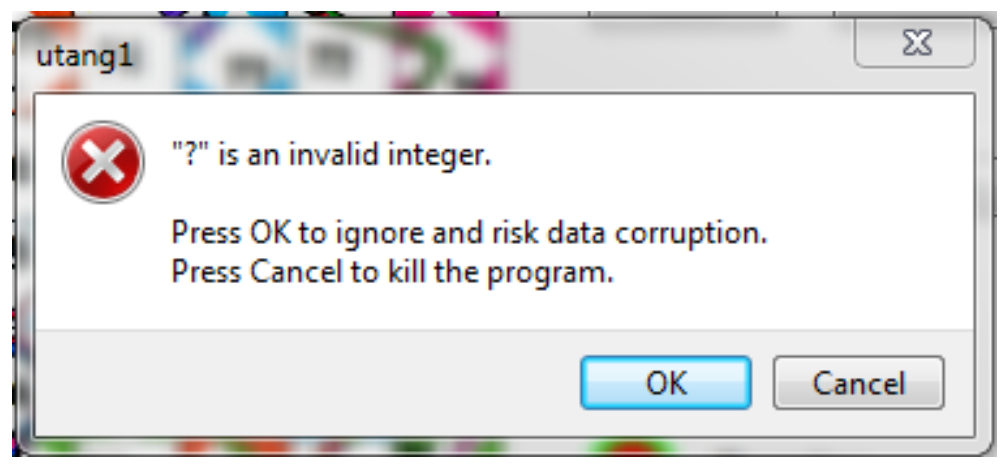

Gambar 8 Pesan kesalahan saat membuka file 
Pertanyaan muncul di dalam memo pada antarmuka. Pertanyaan yang muncul diambil secara acak dari daftar pertanyaan di stringgrid yang disembunyikan. Pemain mengisikan jawaban dari pertanyaan yang muncul pada edit yang berada di bawah memo. Jawaban dicocokkan dengan daftar jawaban di stringgrid pada baris yang bersesuaian dengan pertanyaan. Jawaban dianggap benar jika tulisan jawaban yang dimasukkan persis sama dengan kunci jawaban. Pemain harus memperhatikan besar-kecil huruf, spasi angka maupun karakter khusus pada jawaban, perbedaan sedikit saja dengan kunci jawaban, maka jawaban dianggap salah. Jika jawaban benar dan bidak sedang berada di pangkal tangga, maka bidak akan naik ke ujungnya. Jika jawaban salah dan bidak sedang berada di ekor ular, maka ia akan turun ke kepalanya.

Permainan dapat disimpan dengan menekan tombol 'save' atau melalui menu file $\rightarrow$ simpan. File perlu disimpan untuk mengantisipasi jika karena sesuatu pemain tidak dapat melanjutkan permainan dan ingin melanjutkannya lagi suatu saat nanti. File yang disimpan adalah catatan jumlah pemain, nama masing-masing pemain dan di nomor berapa bidak berada, dan itu dicatat dalam memo. Secara otomatis file yang disimpan diberi nama 'pion.txy' dan dapat diganti dengan nama lain. Pemain dapat membuka permainan yang telah disimpan dengan mengakses menu file $\rightarrow$ buka atau menekan tombol 'open'. Maka bidak akan langsung menempati tempatnya masing-masing seperti sedia kala. Nama pemain dan tempat bidak berada terahir kali dicatat dalam memo. Jika pemain membuka file yang salah atau rusak maka akan muncul pesan kesalahan seperti pada Gambar 8 yang dapat menyebabkan program berhenti. Pembukaan dan penyimpanan file membutuhkan sedikit waktu untuk loading, enkripsi data. File yang disimpan tidak mengandung informasi tentang tingkatan permainan. Pemain dapat bermain pada tingkat mudah, kemudian di tengah permainan menyimpannya dan membukanya kembali dalam tingkatan sulit.

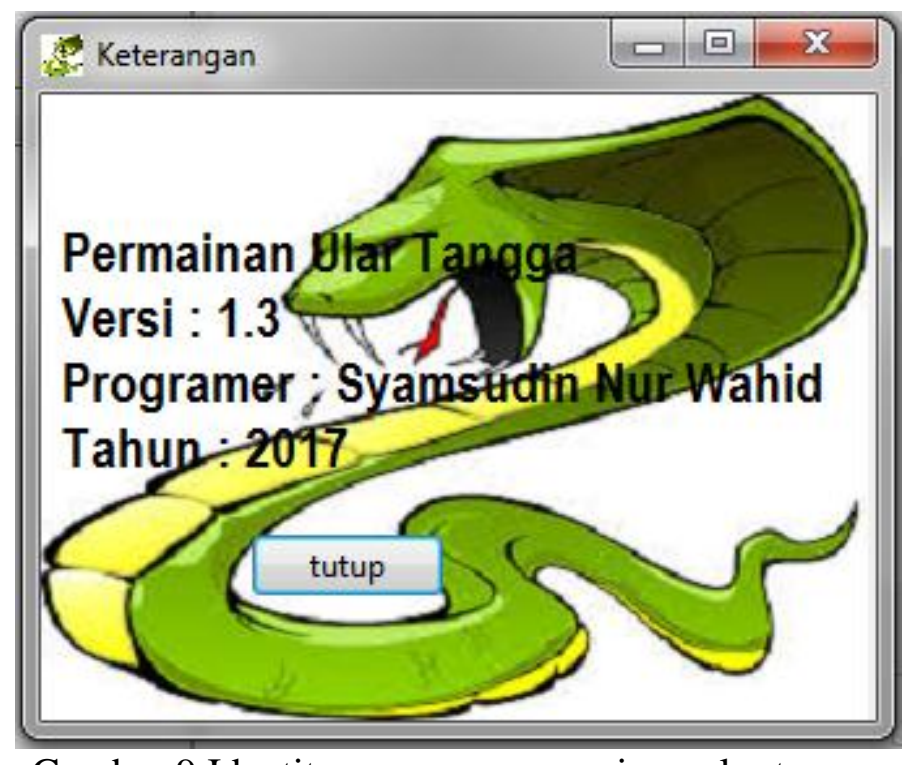

Gambar 9 Identitas program permainan ular tangga

Menu terakhir yang dibahas yaitu menu 'tolong'. Menu 'tolong' berisi 2 submenu, yaitu 'keterangan' dan 'cara bermain'. Submenu 'keterangan' ditunjukkan pada Gambar 9 berisi tentang identitas aplikasi berupa judul aplikasi, versi, pembuat program dan tanggal rilis yang berada dalam sebuah form sendiri sehingga tidak mengganggu jalannya permainan. Sedangkan submenu 'cara bermain' berisi prosedur untuk memanggil file 'Cara bermain game ular tangga .txt' yang berada pada folder dimana aplikasi ini berada. File petunjuk cara 
bermain ketika sudah terbuka dapat disunting dan disimpan kembali dengan nama yang sama. Nama file 'Cara bermain game ular tangga .txt' tidak boleh diubah atau disimpan di folder lain karena menyebabkan file tersebut tidak dapat dipanggil melalui aplikasi utama.

Permainan dapat dimainkan secara individu maupun berkelompok dengan waktu penyelesaian yang bervariasi, tergantung kemampuan setiap orang. Setiap langkah membutuhkan waktu sekitar 1 detik. Permainan yang dimainkan oleh 1 orang dengan 1 kali kesalahan membutuhkan waktu 4 menit. Permainan yang dimainkan dengan 4 bidak dapat diselesaikan paling cepat dalam waktu 7 menit. Waktu tersebut dapat dicapai jika setiap muncul pertanyaan dijawab dengan capat dan tepat. Permaian dapat berjalan lebih lama jika banyak pertanyaan yang jawabannya salah, terutama saat bertemu ular. Adanya ular yang berjajar 6 pada nomor 51-56 dimaksudkan untuk meminimalkan faktor keberuntungan, karena untuk mencapai finish pemain harus menjawab minimal 1 pertanyaan sehingga permainan ini dapat digunakan sebagai sarana evaluasi hasil belajar peserta didik. Namun hal tersebut nampaknya kurang baik untuk membangun motivasi peserta didik yang kemampuan akademisnya rendah karena ia akan frustasi ketika selalu salah saat menjawab pertanyaan dan turun ke nomor bawah. Secara umum aplikasi telah berjalan dengan baik dan sesuai dengan tujuan pembuatan, namun masih memerlukan beberapa pengembangan untuk dapat dipasarkan.

\section{KESIMPULAN}

Telah dibangun program aplikasi game ular tangga untuk media belajar fisika. Aplikasi dibangun menggunakan program Lazarus yang merupakan Pemrograman Pascal berorientasi obyek dalam bentuk open source. Aplikasi telah berjalan dengan baik saat digunakan dan telah sesuai dengan algoritma yang telah dirancang. Permainan dapat disimpan dalam file dan dibuka kembali sesuai dengan keadaan sebelumnya.

Materi persoalan tentang fisika telah dapat disisipkan dalam permainan saat bidak menemui ular atau tangga. Persoalan yang muncul disesuaikan dengan tingkatan yang dipilih oleh pemain, baik mudah, sedang, sulit maupun campuran ketiganya.

Setiap langkah membutuhkan waktu sekitar 1 detik. Permainan yang dimainkan oleh 1 orang dengan 1 kali kesalahan membutuhkan waktu minimal 4 menit. Permainan yang dimainkan dengan 4 bidak dapat diselesaikan paling cepat dalam waktu 7 menit.

Aplikasi game sederhana ini perlu dikembangkan lebih lanjut dengan penambahan suara, animasi dan gambar yang lebih menarik. Hendaknya permainan dapat dimainkan dalam sistem operasi yang lebih memasyarakat, yaitu android sehingga tidak perlu membuka PC untuk memainkannya. Bilamana Lazarus tidak dapat melakukannya, maka perlu digunakan program aplikasi lain, misalnya Adobe Flash, Java, Eclipse dan sebagainya.

Pekerjaan ini didukung sepenuhnya oleh program Penelitian Dosen Pemula dari Direktorat Riset dan Pengabdian Masyarakat, Direktorat Jenderal Penguatan Riset dan Pengembangan Kementerian Riset, Teknologi, dan Pendidikan Tinggi Republik Indonesia. Kepadanya diberikan ucapan terimakasih yang setingg-tingginya.

\section{REFERENSI}

Arsyad, A., 2000. Media Pengajaran. Jakarta: Raja Grafindo Persada.

Arsyad, A., 2007. Media Pembelajaran. Jakarta: Raja Grafindo Persada. 
Jurnal Qua Teknika, Vol. 7 No. 2 September 2017

ISSN 2088 2424(cetak); 2527 3892(elektronik)

UNISBA Blitar, Http://qua.unisbablitar.ejournal.web.id

Syamsudin Nur Wahid, Achendri M Kurniawan. 2017. Rancang Bangun Permainan Ular Tangga untuk Media Belajar Fisika. Jurnal Qua Teknika, (2017), 7(2):43 53.

Dani, M., 2008. Pembelajaran Interaktif dan Atraktif Berbasis Game dan Animasi untuk Pendidikan Dasar dan Menengah di Indonesia. Jakarta, e-Indonesia Initiative 2008 (eII2008).

Novaliendry, D., 2013. APLIKASI GAME GEOGRAFI BERBASIS MULTIMEDIA INTERAKTIF. JURNAL TEKNOLOGI INFORMASI \& PENDIDIKAN, Volume 6, p. 106.

Rodrigues, M. \& Carvalho, P. S., 2013. Teaching physics with Angry Birds: exploring the kinematics and dynamics of the game. Physics Education, p. 431.

Sourceforge, 2017. Lazarus. [Online] Available at: https://www.lazaruside.org/index.php?page=about [Diakses 30 Agustus 2017].

Sugiyo, W., Latifah \& Abidin, Z., 2008. Peningkatan Hasil Belajar Siswa dengan Model Pembelajaran Team Game Tournament Melalui Pendekatan Jelajah Alam Sekitar dan Penilaian Portofolio. Jurnal Inovasi Pendidikan Kimia, Volume 2, pp. 236-243.

Supriana, E., 2011. Matrix Board untuk Mempelajari Hukum Ohm dan Kirchoff pada Pokok Bahasan Listrik Dinamis di SMP dan SMA. Foton, Volume 15, pp. 23-32.

Wahid, S. N., 2012. Pembuatan Software Spada Sebagai Tool Pengisian Mikrokontroler Avr Atmega8535, Malang: tidak dipublikasikan.

Widiastuti, N. I. \& Setiawan, I., 2012. MEMBANGUN GAME EDUKASI SEJARAH WALISONGO. Jurnal Ilmiah Komputer dan Informatika (KOMPUTA), Volume 1, p. 41.

Wikipedia, 2013. Wikipedia bahasa Indonesia. [Online] Available at: https://id.wikipedia.org/wiki/Ular_tangga [Diakses 08 Maret 2016]. 